\title{
Multimedya araçlarının yabancı dil öğretimine etkisi üzerine öğretmen görüşleri ${ }^{1}$
}

\section{Hulusi GEÇGEL²}

\section{Burak PEKER3}

\begin{abstract}
APA: Geçgel, H.; Peker, B. (2020). Multimedya araçlarının yabancı dil öğretimine etkisi üzerine öğretmen görüşleri. RumeliDE Dil ve Edebiyat Araştırmaları Dergisi, (20), 12-22. DOI: 10.2900o/rumelide.791070.
\end{abstract}

$\ddot{O} \mathbf{z}$

$\mathrm{Bu}$ araştırmanın amacı ikinci dil öğretiminde multimedya araçları kullanımına ilişkin öğretmen görüşlerini incelemektir. Araştırmaya yabancı dil olarak Türkçe öğretimi alanında görev yapan 40 öğretmen dâhil edilmiştir. Nitel çalışma yöntemine göre gerçekleştirilen araştırmada öğretmenlerin konuya ilişkin görüşlerinin tespit edilmesinde araştırmacılar tarafından geliştirilen ve 17 açı uçlu sorudan oluşan anket kullanılmıştır. Elde edilen verilerin istatistiksel analizlerinde nitel çalışmalarda sıklıkla kullanılan içerik çözümlemesi yönteminden yararlanılmıştır. Araştırmanın sonunda öğretmen görüşlerine göre yabancı dil öğretiminde kullanılması gerekli olan teknolojik ders materyallerinin başında akıllı tahta, kitap, e-kitap, bilgisayar, tablet bilgisayar, projeksiyon, powerpoint slaytları, sunumları, dinleme metinleri, videolar ve kelime kartlarının geldiği tespit edilmiştir. Öğretmenlerin teknolojik ders materyallerinin yararları hakkındaki görüşleri değerlendirildiği zaman, teknolojik ders materyallerinin ders motivasyonunu arttırdı̆̆ı, bilgilerin daha kalıcı öğrenilmesine katkı sağladıkları, dersleri sıkıcı olmaktan uzaklaştırdığı, kelime telaffuzlarının gelişmesine destek olduğu, birden fazla duyu organına hitap ettiği, bu özellikleri ile öğrencilerin yabancı dil gelişimlerini desteklediği bulunmuştur. Öğretmenlerin yabancı dil öğretiminde kullanılan teknolojik ders materyalleri konusunda karşılaştıkları sorunlar değerlendirildiği zaman, sıklıkla karşılaşılan sorunların başında tablet ve bilgisayar gibi teknolojik aletlerin eksikliği, akıllı tahtaların donması, uygun programların fazla olmaması ve internette yaşanılan kopmalar gibi sorunların geldiği sonucuna ulaşılmıştır.

Anahtar kelimeler: Eğitim, multimedya, teknolojik ders materyalleri, yabancı dil öğretimi

\section{Teachers opinions about the effects of multimedia services on language learning}

\begin{abstract}
Present study aimed to examine teacher views on the use of multimedia tools in second language teaching. A total of 40 teachers working in the field of teaching Turkish as a foreign language were included in the study. In the study conducted according to thequalitative research model, a questionaire composed of 17 open-ended items developed by the researcher was practised in the determination of the views of teachers about the topic. In thestatistical analysis of the data obtained, the content analysis method which is frequently used in qualitative researches was utilized. As a result of the study, it was concluded that smartboard, books, e-book, computer, tablet computer, projection,

1 Bu makale ikinci yazarın Yüksek Lisans tezinden hazırlanmıştır.

2 Dr. Öğr. Üyesi, Çanakkale Onsekiz Mart Üniversitesi, Eğitim Fakültesi, Türkçe ve Sosyal Bilimler Eğitimi Bölümü, Türkçe Eğitimi ABD (Çanakkale, Türkiye), hgecgel@comu.edu.tr, ORCID ID: oooo-00o2-9277-6417 [Makale kayıt tarihi: 15.05.2020-kabul tarihi: 20.09.2020; DOI: 10.29000/rumelide.791070]

3 Bilim Uzmanı, MEB (Çanakkale, Türkiye), burakpeker44@gmail.com, ORCID ID: oooo-0002-7841-5180
\end{abstract}




\begin{abstract}
PowerPoint slides, presentations, listening texts, video tapes and word cards come to the top of the technological course materials that need to be used in language teaching according to the teachers' views. When teachers' views on the benefits of technological course materials were evaluated, it was found that multimedia tools increase the motivation of the lesson, contribute to a more permanent learning, remove lessons from being boring, support word vocabulary development, address multiple sensory organs, with these features multimedia tools support foreign language development of the students. When the problems faced by teachers about the technological course materials used in foreign language teaching were evaluated, the most common problems were mainly problems of the lack of technological tools such as tablets and computers, the freeze in smart-boards, the lack of suitable programs and the breaks in the internet.
\end{abstract}

Keywords: Education, Language teaching, Multimedia, Technological course materials

\title{
Giriș
}

Teknolojik alandaki gelişmelere paralel olarak eğitim teknolojileri alanında da birçok gelişme meydana gelmiştir. Eğitim teknolojilerinin sıklıkla kullanıldığı alanlar içerisinde yabancı dil öğretimi de yer almaktadır. Geleneksel öğretim yöntem ve teknikleri ile kıyaslandığı zaman yabancı dil öğretiminde teknolojik ders materyallerinden yararlanılmasının kalıcı bilgi, ders motivasyonu ve çok yönlü gelişim açısından önemli bir yere sahip olduğu bilinmektedir. Yabancı dil öğretim yöntemleri de bilimsel ve teknolojik ilerlemelere paralel olarak sürekli değişmekte ve gelişmektedir. Baş döndürücü bir hızla gelişen teknoloji, özellikle iletişim teknolojisindeki ilerlemeler, ülkeleri birbirinden ayıran sinırlara rağmen yeryüzündeki tüm insanları birbirine yaklaştırmış ve insanlar gelişmelerden anında haberdar olmak, birbirleriyle iletişim kurmak, ülkeler ve kültürlerarası etkileşimi kolaylaştırmak için yabancı dile daha çok gereksinim duymaya başlamışlardır (Yaman ve Bozdemir, 2010: 220).

1960'lı ylllarda gelişmeye başlayan bilgisayar teknolojisiyle dil öğretiminde teknoloji kullanımı başka bir boyuta taşınmış, özelikle kişisel bilgisayarların ve 1990'lı yıllarda internetin yaygınlaşması ile birlikte bireysel dil öğrenme olanağı doğmuştur. "Bilgisayar Destekli Öğretim" (BDÖ) adı altında yabancı dil öğretiminde dijital ses, metin ve görüntü birlikteliği yani multimedya kullanılmaya başlamıştır. Zaman içinde bu gelişmelere paralel olarak dil laboratuvarlarından bireysel dil öğrenmeye doğru bir dönüşüm sağlanmış ve yapılandırmacı yaklaşım doğrultusunda task based (görev odaklı) öğrenme ön plana çıkmıştır. 2010'lu yıllarda ise özellikle cep telefonlarının akıllı telefon şeklinde gelişmesiyle birlikte Bilgisayar Destekli Dil Öğretimi’nden (Computer Assisted Language Learning / CALL) Cep Telefonu Destekli Dil Öğrenimi’ne (Mobile Phone Assisted Language Learning / MALL) doğru bir geçiş olmaya başlamıştır (Boz ve Çoban, 2015).

Kaynakta teknolojik ders materyallerinin yabancı dil öğretimine etkisine ilişkin yapılan araştırma bulguları da bu görüşü desteklemektedir. Bu noktada yabancılara Türkçe öğretimi alanında görev yapan öğretmenlerin derslerde teknolojik ders materyallerinden yararlanma düzeylerini arttırmaya yönelik çalışmalara ağırlık verilmesi büyük önem arz etmektedir. Bunun sağlanabilmesi için de öncelikli olarak yabancllara Türkçe öğretiminde teknolojik ders materyallerinin yararlarına ilişkin öğretmen görüşlerinin incelenmesi ve öğretmenlerin konuya ilişkin farkındalık düzeylerini arttırmaya yönelik bilimsel çalışmalara ağırlık verilmesi gerekmektedir.

Teknolojik ders materyalleri yabancı dil öğretiminde öğrenci ve öğretmenlere büyük avantajlar sağlamalarına rağmen, amacına uygun ve etkili bir biçimde kullanılmadı̆̆ı zaman teknolojik ders 
materyallerinden kaynaklanan bazı problemler de ortaya çıabilmektedir. Teknolojik ders materyallerinden kaynaklanan sorunların en aza indirilmesi için öncelikli olarak öğretmen görüşlerine göre teknolojik ders materyallerinden kaynaklanan sorunlara ilişkin araştırmalar yapılması önemli bir husustur. Yabancı dil öğretiminde sıklıkla karşılaşılan sorunların başında materyal ve yöntem kaynaklı sorunların geldiği, kaynakta yer alan araştırma bulgularının da bu görüşü desteklediği görülmektedir. Yabancı dil olarak Türkçe öğretiminde teknolojik ders materyallerinin yararları ve teknolojik ders materyallerinden kaynaklanan sorunlar üzerine öğretmen görüşlerine başvurulması sorunun sahada tespiti açısından önem arz etmektedir.

Bu araştırmanın amacı Türkçe Öğretim Merkezleri’nde görev yapan öğretim elemanları ve Geçici Eğitim Merkezlerinde görevli öğretmen görüşlerine göre yabancı dil olarak Türkçe öğretiminde teknolojik ders materyallerinin yararlarının incelenmesi, bunun yanında teknolojik ders materyallerinin kullanım süreçlerinde karşılaşllan sorunların tespit edilmesidir.

\section{Yöntem}

\section{Araştırmanın deseni}

$\mathrm{Bu}$ araştırmada nitel araştırma desenlerinden durum çalışması deseni kullanılmıştır. Durum çalışması "bir durumun derinlemesine çalışılıp betimlenmesi” tanımların ortak noktasıdır. Durum çalışması olaylar ve davranışlar hakkında zengin ve önemli bakış açıları sağlamasından dolayı önemli bir bilgi edinme yöntemidir. Durum çalışmaları, karmaşık bir durumun geniş bir şekilde tanımlanarak ve kendi doğal ortamında bileşenlerinin belirlenerek boylamsal olarak çalışılmasına imkân sağlar (Subaşı ve Okumuş, 2017: 425). Bu kapsamda yabancı dil olarak Türkçe öğretiminde görev yapan öğretmenlere araştırma problemlerine cevap bulmaya yönelik sorular yöneltilmiş, daha sonra elde edilen öğretmen görüşleri bütüncül bir yaklaşım ile değerlendirilerek araştırma bulguları elde edilmiştir.

\section{Çalışma grubu}

Araştırmanın çalışma grubunda Türkiye'nin farklı üniversitelerinde Türkçe Öğretim Merkezleri’nde çalışan 40 öğretmen yer almaktadır. Araştırmanın verileri 2016-2017 eğitim ve öğretim yllı içerisinde toplanmiştır.

\section{Veri toplama aracı}

Araştırmada veri toplama aracı olarak yarı yapılandırılmış görüşme formu kullanılmıştır. Araştırmada öncelikle alanyazın taraması yapılmıştır. Bu tarama doğrultusunda araştırma soruları belirlenmiştir. Araştırma soruları alan uzmanları tarafından değerlendirilmiş, daha sonra pilot uygulama yapılmıştır. Uygulamanın ardından araştırma sorularına son hali verilerek çalışma grubuna uygulanmıştır.

\section{Veri analizi}

Araştırmada nitel analiz yöntemlerinden içerik analizi yöntemi kullanılmıştır. Bu kapsamda öncelikli olarak katılımcıların kendilerine yöneltilen sorulara verdikleri yanıtlar gruplara ayrılmış, daha sonra her soruya verilen yanıtlar paragraflar halinde raporlaştırılmıştır. Kodlama sürecinde birbirine yakın anlamlara sahip olan yanıtlar aynı başlıklar altında toplanmıştır. Araştırmanın analizlerinin geçerlik ve güvenirliğini artırmak için bulgular farklı iki alan uzmanı tarafından kodlanmıştır. 


\section{Bulgular ve yorum}

Araştırma kapsamında yer alan katılımcllara "Yabancılara Türkçe öğretiminde okuma becerisi kazandırmak için derste hangi teknolojik materyalleri kullanıyorsunuz?” sorusu yöneltilmiştir. Elde edilen sonuçlara göre katılımcıların çoğunluğu; akıllı tahta, kitap, e-kitap, z-kitap, bilgisayar, projeksiyon, powerpoint slaytları, videolar, Türkçe alt yazılı şarkı ve filmler yardımı ile yapılabileceği görüşünde birleşmişlerdir.

Katılımcılar, "Yabancılara Türkçe öğretiminde konuşma becerisi kazandırmak için derste hangi teknolojik materyalleri kullanıyorsunuz?" sorusuna ağırlıklı olarak; akıllı tahta, tablet, PDA, mobil, bilgisayar, projeksiyon ve ses kayıt cihazlarının yanı sıra video, kitaplarda yer alan konuşma metinleri ve filmlerde yer alan diyalogların Türkçe öğretiminde konuşma becerilerini kazandırabileceği üzerine görüş bildirmişlerdir.

"Sizce yabancılara Türkçe öğretiminde konuşma becerisi kazandırmak için derste hangi teknolojik materyallerin kullanılması faydalıdır? Neden?” sorusuna katılımcılardan çoğunluğu; kısa videoları, filmleri, akıllı tahta ve projeksiyon yardımı ile anlatılan sunular ve görselleri faydalı bulduklarını belirtmişlerdir.

Katılımcılara, "Yabancılara Türkçe öğretiminde yazma becerisi kazandırmak için derste hangi teknolojik materyalleri kullanıyorsunuz?” sorusu yöneltilmiştir. Katılımcıların çoğunluğu; kâğıt kalem kullanımın yetmediğini, bu açıdan video, afiş, karikatürler, gazeteler, dergiler, ders kitapları, akıllı tahta, bilgisayar, tablet gibi teknolojik cihazlar içerisinde yer alan yazma programlarının, boşluk doldurma, hikâye, öykü tamamlama gibi unsurların kullanıldığı görüşünü belirtmişlerdir.

"Sizce yabancılara Türkçe öğretiminde yazma becerisi kazandırmak için derste hangi teknolojik materyallerin kullanılması faydahıdır? Neden?” sorusuna, katılımcıların çoğunluğu, kullanılan materyallerin bulunabilmesi ve uygulanabilirliklerinin kolay olduğu üzerine görüş bildirmişlerdir.

"Yabancılara Türkçe öğretiminde dinleme becerisi kazandırmak için derste hangi teknolojik materyalleri kullanıyorsunuz?” sorusu karşısında katılımcıların büyük çoğunluğu; video, cd, filmler, akıllı tahta dinleme metinleri, bilgisayar, ses kayıtları, tablet, projeksiyon ve şarkıların dil öğrenme konusunda materyal olarak kullandıkları görüşünde birleşmişlerdir.

Katılımcılara "Sizce yabancılara Türkçe öğretiminde dinleme becerisi kazandırmak için derste hangi teknolojik materyallerin kullanılması faydahıdır? Neden?” sorusu yöneltilmiştir. Elde edilen sonuçlara göre araştırmaya dâhil olan katılımcıların çoğunluğu; CD'lerin, filmlerin, akıllı tahta dinleme metinlerinin, videoların yanı sıra bilgisayar, projeksiyon ve tabletlerin yararlı olacağı görüşünde birleşmişlerdir.

Çalışmaya dâhil olan katılımcıların "Sizce yabancılara Türkçe öğretiminde kelime öğretiminde hangi teknolojik materyallerin kullanılması faydalıdır? Neden?” sorusu yöneltilmiştir. Çalışmaya dâhil olan katılımcılardan elde edilen bulgulara göre çoğunluğunun; kelime kartları, ders kitaplar, akıllı tahta ve bilgisayarda yer alan eğitici programlar, afişler, posterler, slaytlar gibi materyallerin kullanımları gerek ulaşılabilirlikleri gerekse de kullanımlarının kolay olmalarından dolayı tercih edildiği görüşü üzerinde birleşerek ders işlenişi sırasında sıkıcılıktan uzak kalınmaya faydalı olduğu görüşü hâkimdir. 
Katılımcılara "Yabancılara Türkçe öğretiminde dil bilgisi öğretiminde derste hangi teknolojik materyalleri kullanıyorsunuz?” sorusu yöneltilmiştir. Çalışmaya katılan katılımcılardan elde edilen bulgulara göre araştırmaya katılanların çoğunluğunun; akıllı tahta, kitap, e-kitap, ders kitabı, bilgisayar, projeksiyon, powerpoint slaytları, sunumları, videolar, Türkçe alt yazılı şarkı ve filmler yardımı ile yapılabileceği görüşünde birleşmişlerdir.

Katılımcılara "Sizce yabancllara Türkçe öğretiminde dil bilgisi öğretiminde hangi teknolojik materyallerin kullanılması faydalıdır? Neden?” sorusu yöneltilmiştir. Katılımcılardan elde edilen bulgulara göre çalışmaya katılanların çoğunluğu; kitap, akıllı tahta, bilgisayar, afiş çalışmaları, slayt ve kelime kartlarının kullanılmasının faydaları olacağı hususunda görüş bildirmişlerdir

Bu bölümde çalışma kapsamında yer alan katılımcıların "Siz yabancılara Türkçe öğretiminde derste hangi teknolojik materyallerin eksikliğini yaşıyorsunuz?” sorusu yöneltilmiştir. Çalışmaya katılanlardan elde edilen bulgulara göre katılımcıların çoğunluğu; yeni gelişen bir bölüm olmasından dolayı teknolojik materyaller konusunda henüz istenilen seviyede olamadıklarını, buna karşın eldeki mevcut materyaller ile yetinmeye çalıştıkları hususunda görüş bildirmişlerdir.

Bu başlık altında çalışmaya dâhil olan katılımcılara "Yabancılara Türkçe öğretiminde kullanılan ya da kullanılması gereken teknolojik materyallerle ilgili, yeterli bilgi ve beceriye sahip olduğunuzu düşünüyor musunuz? Neden?” sorusu yöneltilmiştir. Çalışmaya dâhil olan katılımcılardan elde edilen bulgulara göre araştırmaya katılanların çoğunluğu; Türkçe öğretiminde kullanılan ya da kullanılması gereken teknolojik materyalleri kullanma becerisine sahip olduklarını vurgulamışlardır. Katılımcılar bu materyalleri hem kullanımı hem de ulaşılabilirliklerinin kolay olmasından dolayı seçtiklerini belirtmişlerdir.

Bu bölümde çalışma kapsamında yer alan katılımcılara "Yabancılara Türkçe öğretiminde derste teknolojik materyallerle ilgili yaşadığınız sorunlar var mı? Varsa nelerdir?” sorusu yöneltilmiştir. Çalışma kapsamında yer alan katılımcılardan elde edilen bulgulara göre katılımcıların bazıları hiçbir sorun yaşamadı̆̆ını söylemesine karşın, çoğunluğu açısından; akıllı tahtaların donması, uygun programların fazla olmaması, internette yaşanılan kopmalar, tablet ve bilgisayar gibi teknolojik aletlerin eksikliği gibi sorunlar yaşadıklarını vurgulamışlardır.

"Sizce yabancılara Türkçe öğretiminde derste kullanılan teknolojik materyallerin olumsuz yönleri var mıdır? Varsa nelerdir?” sorusuna katılımcıların çoğunluğu; teknolojik materyallerin amaçlar doğrultusunda kullanıldığı sürece herhangi bir zararı olmadığı konusunda görüş bildirmişlerdir.

"Sizce yabancılara Türkçe öğretiminde derste kullanılmak üzere geliştirilen teknolojik materyallerin eksik yönleri var mıdır? Varsa nelerdir?” sorusuna katılımcıların çoğunluğu; birtakım eksiklikler olduğu konusunda fikir birliğine varmışlardır.

Araştırma kapsamında yer alan katılımcılara okuma, konuşma, yazma ve dinleme becerilerinde kullanılan teknolojik materyaller ve faydaları konusunda görüşlerini alabilme adına toplam sekiz adet soru yöneltilmiştir. Katılımcılardan alınan yanıtlar doğrultusunda katılımcıların yabancılara Türkçe öğretiminde kullanıldıkları teknolojik materyallerin çoğunlukla; akıllı tahta ve uygulamaları, video, slayt, gazete, dergi, kelime kartları, karikatürler, CD’ler, projeksiyon cihazları, tablet, mobil cihazlar ve internet gibi uygulamalar ve cihazlar olduğu gözlenmiştir. 
Katılımcıların genel görüşü olarak; kullanılan bu cihazların ve uygulamaların yabancılara Türkçe öğretim konusunda okuma, konuşma, yazma ve dinleme becerilerini bir arada geliştirebilme imkânı sağlaması açısından önemli olduğu görüşü üzerinde birleşmişlerdir.

Yabancllara Türkçe öğretiminde kelime ve dil bilgisi öğretimine ilişkin görüşler kapsamında, katılımcılar çoğunlukla; Türkçe öğretimi konusunda kelime ve dil bilgisini ayrı bir bütün olarak işlenmeye çalışılmasına karşın, bir önceki başlıkta değinilen okuma, konuşma, yazma ve dinleme becerileri içerisinde de birebir sezdirilmeden öğrencilere verilmeye çalışıldığı konusunda görüş bildirmişlerdir.

"Yabancılara Türkçe Öğretiminde Kullanılan Teknolojik Materyallere İlişkin Genel Değerlendirmeler" başlığı altında araştırmanın son beş sorusunda yabancılara Türkçe öğretiminde kullanılan teknolojik materyallerin uygulayıcılar tarafından kullanılabilme düzeyleri, eksiklik yaşama durumları, materyallerle ilgili yaşadıkları sorunlar, materyallerin olumsuz yönleri ve eksik yönleri konusunda görüşleri alınmıştır. Yapılan incelemede katılımcıların genel çoğunluğu teknolojik materyalleri kullanma becerisine sahip olduklarını belirtmişlerdir. Uygulayıcılar yabancılara Türkçe öğretimi sırasında kurum içerisinde teknolojik materyallerin kısmen yetersiz olduğu, uygulamada kullanılan programların istenilen düzeyde olmadığı görüşündedirler.

\section{Tartışma, sonuç ve öneriler}

Araştırmada yabancılara Türkçe öğretiminde okuma becerisi kazandırmak için derste kullanılması istenilen teknolojik materyaller hakkındaki öğretmen görüşleri değerlendirildiği zaman, öğretmenlerin büyük bir bölümünün yabancılara Türkçe öğretiminde akıllı tahta, kitap, e-kitap, bilgisayar, projeksiyon, powerpoint slaytları, sunumları, videolar, Türkçe alt yazılı şarkı ve filmlerden yararlanılması gerektiği görüşünde birleştikleri tespit edilmiştir. Arslan ve Adem (2010: 66) tarafından yapılan benzer bir çalışmada yabancılara Türkçe öğretiminde kullanılabilecek görsel ders materyallerinin incelenmesi amaçlanmış, araştırmada yabancılara Türkçe öğretiminde kullanılabilecek görsel ders materyallerinin başında video film, televizyon, DVD-VCD oynatıcı, bilgisayar, projeksiyon ve diğer işitsel ders materyallerinin geldiği rapor edilmiştir.

Araştırmada yabancılara Türkçe öğretiminde konuşma becerisi kazandırmak için derslerde kullanılan teknolojik materyaller konusundaki öğretmen görüşleri değerlendirildiği zaman, konuşma becerisini geliştirmeye yardımcı olacak teknolojik ekipmanların başında akıllı tahta, tablet, PDA, mobil, bilgisayar, projeksiyon ve ses kayıt cihazlarının yanında video, kitaplarda yer alan konuşma metinleri ve filmlerde yer alan diyalogların geldiği tespit edilmiştir. Yabancı dil olarak Türkçe konuşma becerisinin kazandırılmasını etkileyen unsurlar başında öğrencilerin seviyeleri, sınıf ortamının uygunluğu ve işlenecek konunun içeriği gibi unsurlar gelmektedir. Bunun yanında Türkçe konuşma becerisinin geliştirilmesinde ve kazandırılmasında uygun yöntem ve tekniklerin kullanılması gerektiğine vurgu yapılmaktadır (Göçer, 2015). Yapılan bu araştırmada elde edilen bulgular değerlendirildiği zaman, araştırmaya katılan öğretmenlerin yabancı dil olarak Türkçe konuşma becerisi öğretiminde teknolojik ders materyalleri kullanılmasına önem verdikleri görülmektedir. Arslan ve Adem (2010) tarafindan yapılan araştırmada da yabancılara Türkçe öğretiminde bilgisayar destekli ders materyallerinden yararlanılmasının öğrenci motivasyonunu arttırmaya katkı sağladığına vurgu yapılmıştır. Yapılan bu araştırmaya katılan öğretmen görüşlerinin de bu düşünceleri desteklediği görülmektedir. 
Literatürde yer alan araştırma bulguları ve araştırmacı görüşlerinin de yapılan bu araştırmada elde edilen sonuçlar ile paralellik göstermektedir. Akalın'a (1996) göre, konuşma becerisinin geliştirilmesinde yararlanılan video filmler ile bireyin sözcükleri telaffuz becerileri gelişmektedir. Araştırmada yabancılara Türkçe öğretiminde yazma becerisi kazandırmak için derslerde kullanılan teknolojik materyaller konusundaki öğretmen görüşleri değerlendirildiği zaman, yazma becerisini geliştirmeye yardımcı olacak teknolojik ekipmanların başında video, afiş, kelime kartları, karikatürler, gazeteler, dergiler, ders kitapları, akıllı tahta, bilgisayar, tablet gibi teknolojik cihazlar içerisinde yer alan yazma programlarının, boşluk doldurma, hikâye ve öykü tamamlama gibi teknolojik materyal ya da yöntemlerin geldiği tespit edilmiştir. Araştırmada elde edilen bulgular, öğretmenlerin yazma öğretimine birçok ders materyallinden yararlanılması konusunda hemfikir olduklarını ortaya koymaktadır.

Yabancılara Türkçe öğretiminde yazma becerisi kazandırmak için derste kullanılan teknolojik materyallerin faydalarına ilişkin öğretmen görüşleri değerlendirildiği zaman, birden fazla duyu organına hitap eden materyallerin yazma becerisinin gelişimine katkı sağlayacağı, kelime kartlarının yazma becerisi için gerekli olan kelime haznesinin gelişimine katkı sağlayacağı, görsel teknolojik materyallerin öğrenilmesi ve telaffuzu zor olan kelimelerin öğrenilmesine yardımcı olacağı sonuçlarına ulaşılmıştır.

Araştırmada yabancılara Türkçe öğretiminde dinleme becerisi kazandırmak için derste kullanılması istenilen teknolojik materyaller hakkındaki öğretmen görüşleri değerlendirildiği zaman, öğretmenlerin büyük bir bölümünün yabancılara Türkçe dinleme öğretiminde video, cd, filmler, akıllı tahta dinleme metinleri, bilgisayar, ses kayıtları, tablet, projeksiyon ve şarkılardan yararlanılması gerektiği görüşünde birleştikleri tespit edilmiştir. Dinleme becerisi sözlü anlam, işlem ve etkileşim boyutlarından meydana gelen kompleks bir yapıya sahiptir. Bu nedenle dil öğretiminde dinleme becerisinin geliştirilmesinde birçok yöntem kullanılmaktadır (Güneş, 2013). Bu yöntemler içerisinde teknolojik ders materyalleri de bulunmakta olup, literatürde yer alan araştırmalarda da dinleme becerisinin geliştirilmesinde çeşitli teknolojik ders materyallerinden yararlanıldığına vurgu yapılmaktadır (Şengül, 2012). Araştırmaya katılan öğretmen görüşlerinin de bu düşünceyi desteklediği görülmektedir.

Kelime hazinesi bireyin anlama ve anlatma becerisini doğrudan etkileyen bir olgu olduğu için (Özbay ve Melanlığlu, 2008) yabancı dil öğrenen öğrencilerin kelime hazinelerinin geliştirilmesinde kullanılacak yöntem ve materyaller iletişim becerilerinin geliştirilmesinde önemli bir yere sahiptir. Yapılan bu araştırmada yabancılara Türkçe öğretiminde kelime dağarcığını geliştirmek için derste kullanılması istenilen teknolojik materyaller hakkındaki öğretmen görüşleri değerlendirildiği zaman, öğretmenlerin büyük bir bölümünün söz varlığının geliştirilmesinde kelime ve kavram kartları, slayt, video, CD, radyo, bilgisayar, film, sokak röportajları, ses kayıt cihazları, akıllı tahta ve uygulamalarının kullanılması gerektiği görüşünde birleştikleri tespit edilmiştir. Literatürde yer alan benzer araştırma bulguları da kelime dağarcığının geliştirilmesinde, görsel ders materyallerinden (Özbay ve Melanlığlu, 2008), bilgisayar destekli öğretim yöntemlerinden ve CD’lerden sıklıkla yararlanıldığı görüşünü desteklemektedir (Arslan ve Adem, 2010).

Araştırmada yabancılara Türkçe öğretiminde dil bilgisi becerisini geliştirmek için derste kullanılması istenilen teknolojik materyaller hakkındaki öğretmen görüşleri değerlendirildiği zaman, öğretmenlerin büyük bir bölümünün yabancılara Türkçe öğretiminde dil bilgisi becerisinin geliştirilmesinde çalışma kitapları ve boşluk doldurma, akıllı tahta, kitap, e-kitap, ders kitabı, bilgisayar, projeksiyon, powerpoint slaytları, sunumları, videolar, Türkçe alt yazılı şarkı ve filmlerin kullanılması gerektiği görüşünde birleştikleri tespit edilmiştir. Elde edilen bu bulgulara göre, araştırmaya katılan öğretmenlerin dil bilgisi 
gelişiminin desteklenmesinde teknolojik ders materyallerinden yararlanılmasının faydalı olacağını düşündükleri söylenebilir.

Yabancllara Türkçe öğretiminde dil bilgisi becerisini geliştirmek için derste kullanılan teknolojik materyallerin faydalarına ilişkin öğretmen görüşleri değerlendirildiği zaman, öğretmenlerin dil bilgisi becerisini geliştirmede kullanılan teknolojik materyallerin okuma, konuşma, yazma ve dinleme becerileri ile iç içe olmasından dolayı yararlı olacağı görüşünde birleştikleri sonucuna ulaşılmıştır.

Yabancı dil olarak Türkçe öğretiminin başarılı olmasında kullanılan ders materyallerinin önemli bir yere sahip olduğu bilinmektedir (Eryaman ve Kana, 2012). Araştırmaya katılan öğretmenlerin yabancılara Türkçe öğretiminde derste kullanılan teknolojik materyallerin eksikliğini yaşama durumları değerlendirildiği zaman, yabancılara Türkçe öğretiminde kullanılacak teknolojik materyaller konusunda henüz yeterli donanıma sahip olunmadığı, teknolojik materyaller ile internet ve program kullanımlarında bazı eksiklikler olduğu, bunun yanında düzeye uygun teknolojik ders materyali bulma konusunda sorunlar yaşandığı sonuçlarına ulaşılmıştır. Maden ve diğerlerine (2015) göre, Türkçe öğretiminde sıklıkla karşılaşılan sorunların başında ders materyali eksikliği ile yararlanılan kaynak ve yöntemlerin eksikliği gibi sorunlar gelmektedir. Literatürde yer alan benzer çalışmalarda da yabancı dil olarak Türkçe öğretiminde materyal kaynaklı sorunların sıklıkla yaşandığına vurgu yapılmıştır (Kan ve diğerleri, 2013). Bu kapsamda araştırmada elde edilen öğretmen görüşlerinin literatür ile uyumlu olduğu söylenebilir.

Yabancı dil olarak Türkçe öğretiminde öğretmenlerin karşılaştıkları başlıca sorunlar arasında materyal eksikliğinden kaynaklanan sorunlar önemli bir yer tutmaktadır. Yapılan bu araştırmada öğretmenlerin yabancılara Türkçe öğretiminde kullanılan materyaller konusunda yaşanan sorunlar hakkındaki görüşleri değerlendirildiği zaman, en sık karşılaşılan problemlerin başında akıllı tahtaların donması, uygun programların fazla olmaması, internette yaşanılan kopmalar, tablet ve bilgisayar gibi teknolojik aletlerin eksikliği gibi sorunların geldiği tespit edilmiştir. Literatürde yabancı dil olarak Türkçe öğretimine ilişkin sorunların ele alındığı araştırmalarda genellikle Türkçe’nin yapısından ya da alfabeden kaynaklanan sorunların ele alındığı görülmekte olup (Arslan, 2014; Arslan ve Klicic, 2015; Şengül, 2014), materyal kaynaklı sorunlara yeterli düzeyde değinilmediği görülmektedir.

Araştırmada öğretmenlerin yabancılara Türkçe öğretiminde kullanılan teknolojik materyallerin olumsuz yönleri hakkındaki görüşleri değerlendirildiği zaman, sorunların başında materyallerin öğrencileri hazırcılığa alıştırması, derslerin amaçlarına uygun kullanılmamaları ve bazı görsel teknolojik materyallerin öğrencilerin beynini pasif hale getirmelerinin geldiği tespit edilmiştir. Buna karşlık öğretmenlerin büyük bir bölümünün teknolojik ders materyalleri konusunda herhangi bir olumsuz görüş belirtmedikleri, hatta teknolojik ders materyalleri kullanılmasının büyük bir önem arz ettiği görüşünde birleştikleri sonucuna ulaşılmıştır.

Araştırmada öğretmenlerin yabancllara Türkçe öğretiminde kullanılan teknolojik materyallerin eksik yönleri hakkındaki görüşleri değerlendirildiği zaman, materyallerin eksik yönlerinin başında cihazların kullanımlarının biraz zaman alması, programlarda konuların bazen çok basit olması ya da öğrencilerin seviyesine uygun olmaması, bunun yanında dil öğretimi konusunda yetersiz kalmalarının geldiği sonucuna ulaşılmıştır.

Yabancı dil öğretiminde birtakım sorunlarla karşılaşılmasının beklenen bir durum olduğu bilinmekle beraber, yabancı dil öğretiminde karşılaşılan problemler arasında kullanılan ders materyallerinin 
önemli bir yere sahip olduğu belirtilmektedir (Nurlu ve Kutlu, 2015; Maden ve diğerleri, 2015). Literatürde yer alan araştırma bulguları ve araştırmacı görüşleri de bu düşünceyi desteklemektedir. Kalfa (2014) tarafından gerçekleştirilen araştırmada dil öğretiminde kaynaklanan birçok sorun olduğu belirtilmiş, bu sorunlar içerisinde materyal eksikliğinin önemli bir sorun olduğu ifade edilmiştir. Aynı araştırmada dil öğretiminde kitaplar dışında diğer ders materyallerine başvurulmamasının önemli bir sorun teşkil ettiğine vurgu yapılmıştır.

Araştırmaya katılan öğretmenlerin yabancı dil olarak Türkçe öğretiminde kullanılan teknolojik materyaller hakkındaki görüşlerinin ele alındığı bu araştırmada aşağıdaki sonuçlara ulaşılmıştır:

Katılımcıların yabancı dil olarak Türkçe öğretiminde okuma, dinleme, konuşma, yazma, dil bilgisi ve kelime öğretiminde kullanılması gerektiğini düşündükleri teknolojik materyallerin başında akıllı tahta, kitap, e-kitap, bilgisayar, tablet bilgisayar, projeksiyon, powerpoint slaytları, sunumları, dinleme metinleri, videolar ve kelime kartlarının geldiği tespit edilmiş, araştırmada elde edilen bulguların kaynak ile paralellik gösterdiği sonucuna ulaşılmıştır.

Katılımcıların yabancılara Türkçe öğretiminde kullanılan teknolojik ders materyallerinin yararlarına ilişkin görüşleri değerlendirildiği zaman, teknolojik ders materyallerinin ders motivasyonunu arttırdığı, dersleri sıkıcı olmaktan uzaklaştırdığı, bilgilerin daha kalıcı öğrenilmesine katkı sağladıkları, kelime telaffuzlarının gelişmesine destek oldukları, birden fazla duyu organına hitap ettikleri için öğrencilerin dil gelişimlerini destekledikleri, teknolojik ders materyallerinin aynı anda birden fazla dil becerisinin gelişimine katkı sağladığı sonucuna ulaşılmıştır.

Araştırmaya katılan öğretmenlerin yabancı dil olarak Türkçe öğretiminde kullanılan teknolojik ders materyalleri hakkındaki bilgi ve yeterlik düzeylerinin yüksek olduğu tespit edilmiş, buna karşllık öğretmenlerin eğitim sürecinde teknolojik ders materyali kaynaklı bazı sorunları olduğu görülmüştür. Öğretmenlerin en sık karşılaştıkları sorunların başında uygun programların fazla olmaması, tablet ve bilgisayar gibi teknolojik aletlerin eksikliği, akıllı tahtaların donması, internette yaşanılan kopmalar gibi sorunların geldiği sonucuna ulaşılmıştır.

\section{Öneriler}

Araştırmada elde edilen bulgular ve ilgili literatür ışığında aşağıdaki önerilerde bulunulabilir:

Yabancı dil olarak Türkçe öğretimine ilişkin öğretmen görüşleri değerlendirildiğinde öğretmenlerin genel olarak teknolojik ders materyallerini yararlı buldukları belirlenmiş, bu sonucun literatürle uyumlu olduğu görülmüştür. Bu kapsamda yabancılara Türkçe öğretiminde teknolojik ders materyallerinden daha sık yararlanılmasına yönelik yasal ve yönetsel bazı düzenlemeler yapılabilir.

Araştırmada her ne kadar öğretmenlerin teknolojik ders materyalleri konusundaki yeterlik düzeyleri yüksek bulunmuş olsa da literatürde yer alan çalışmalarda yabancılara Türkçe öğretimi konusunda yeterli deneyime sahip personel bulunmadığına vurgu yapılmaktadır. Bu noktada lisans düzeyinde Yabancılara Türkçe Öğretimi Programları ihtiyaç doğrultusunda öğrenci sayıları ve program içerikleri yönüyle gözden geçirilmelidir. Bakanlık tarafından teknolojik materyallerin kullanımı ve derslere uygun materyal geliştirme konusunda öğretmenler hizmet içi eğitimden geçirilebilir.

Araştırmada öğretmenlerin teknolojik ders materyalleri konusunda bazı sorunlar yaşadıkları tespit edilmiştir. Bu kapsamda ders materyallerinin sayısının arttırılması, ders materyallerinde görülen teknik 
sorunların en aza indirilmesi, öğretmenlerin ders materyallerinin kullanımı konusunda bilinçlendirilmeleri, ders materyallerinin öğrenci seviyesine ve gereksinimlerine uygun hale getirilmesi gibi tedbirler alınabilir.

Yabancı dil olarak Türkçe öğretiminde kullanılan teknolojik ders materyallerinin etkinliğinin incelendiği araştırmalar yapılabilir. Özellikle deney ve kontrol grupları ile ön-son test araştırma modeline uygun olarak gerçekleştirilen çalışmalar yapılabilir. Böylece hem hangi ders materyallerinin yabancı dil olarak Türkçe öğretiminde daha etkin olduğuna hem de teknolojik ders materyallerinim yabancı dil olarak Türkçe öğretimindeki etkilerine yönelik bulgulara ulaşılabilir.

Farklı ülkelere ve farklı anadillere mensup öğrencilerin Türkçe öğretiminde karşılaşacakları sorunların da farklılık göstermesi beklenmektedir. Bu durum teknolojik ders materyallerinin kullanımında karşılaşılacak sorunları da etkileyebilmektedir. Bu kapsamda farklı anadillere sahip öğrencilerle Türkçe öğretimi sürecinde teknolojik ders materyali kullanımında karşılaşılan sorunların ele alındığı çalışmalar yapılabilir. Elde edilen bulgular ışı̆̆ında teknolojik ders materyallerinin seçiminde öğrencilerin anadillerine uygun yöntemler kullanılabilir.

Günümüzde tüm dünyada eğitim sistemleri içerisinde teknolojik ders materyallerine yer verilmekte olup birçok derste teknolojik ders materyallerinden yararlanıldığı bilinmektedir. Yabancı dil olarak Türkçe öğretiminde de teknolojik ders materyallerinden yararlanılmakta olup hem bu araştırmada elde edilen öğretmen görüşleri hem de literatürde yer alan çalışma bulguları teknolojik ders materyali kullanımının yabancı dil olarak Türkçe öğretimine katkı sağladığını ortaya koymaktadır. Bu noktada yabancı dil olarak Türkçe öğretiminin yapıldığı eğitim kurumlarının teknolojik ders materyalleri açısından zenginleştirilmesine yönelik yasal ve idari düzenlemeler yapılabilir.

\section{Kaynakça}

Akalın, A. (1996). Yabancı dil öğretiminde araç, gereç ve otantik dokümanların kullanılması. Atatürk Üniversitesi Türkiyat Araştırmaları Enstitüsü Dergisi, 4, 143-153.

Arslan, M. (2014). Öğrenenler açısında Türkçe’nin yapısal özelliklerinin yabancı dil olarak öğrenimine etkisi: Bosna Hersek örneği. Eğitim ve Bilim, 39(174), 189-200.

Arslan, M. ve Adem, E. (2010). Yabancılara Türkçe öğretiminde görsel ve işitsel araçların etkin kullanımı. Dil Dergisi, 147, 63-86.

Arslan, M. ve Klicic, E. (2015). Yabancı dil olarak Türkçe öğretiminde yazma becerisinin gelişiminde karşılaşılan sorunlar: Bosna Hersek örneği. Kırıkkale Üniversitesi Sosyal Bilimler Dergisi, 5(2), 169-182.

Boz, M. S. ve Çoban, Ö. (2015). Yabancı Dil Eğitiminde teknoloji kullanımı. Ankara: MEB Yenilik ve Eğitim Teknolojileri Genel Müdürlüğü.

Eryaman, Y. ve Kana, F. (2012). Yabancı dil olarak Türkçe öğretiminde program sorunu. Aziz Kılınç, Abdullah Şahin (Editörler). Yabancı dil olarak Türkçe öğretimi (ss. 147-164). 2. Baskı. Ankara: Pegem Akademi.

Göçer, A. (2015). Türkçenin yabancı dil olarak öğretiminde konuşma becerisinin kazandırılması. Trakya Üniversitesi Sosyal Bilimler Dergisi, 17(2), 21-36.

Güneş, F. (2013). Türkçe öğretimi: Yaklaşımlar ve modeller. Ankara: Pegem Akademi.

Kalfa, M. (2014). Yabancılara Türkçe öğretiminde temel düzeydeki öğrencilerin eğitsel oyunlarla yazma becerilerinin geliştirilmesi. Hacettepe Üniversitesi Türkiyat Araştırmaları Dergisi, 20, 85-102. 
Kan, M. O., Sülüşoğlu, B. ve Demirel, Ö. (2013). Yabancı dil olarak Türkçe öğretimi programı ile ilgili okutman ve öğrenci görüsslerinin değerlendirilmesi. Mustafa Kemal Üniversitesi Sosyal Bilimler Enstitüsü Dergisi, 1O(24), 29-42.

Karataş, Z. (2015). Sosyal bilimlerde nitel araştırma yöntemleri. Manevi Temelli Sosyal Hizmet Araştırmaları Dergisi, 1(1), 62-80.

Maden, S., Dincel, Ö. ve Maden, A. (2015). Türkçeyi yabancı dil olarak öğrenenlerin yazma kaygıları. Uluslararası Türkçe Edebiyat Kültür Eğitim Dergisi, 4(2), 748-769.

Nurlu, M. ve Kutlu, A. (2015). Türkçenin yabancı dil olarak öğretiminde temel seviye a1 yazma sorunları: Afganistan örneği. Kara Harp Okulu Bilim Dergisi, 25(2), 67-87.

Özbay, M. ve Melanlığlu, D. (2008). Türkçe eğitiminde kelime hazinesinin önemi. Yüzüncü Yll Üniversitesi Eğitim Fakültesi Dergisi, 5(1), 30-45.

Subaşı, M. ve Okumuş, K. (2017). Bir araştırma yöntemi olarak durum çalışması. Atatürk Üniversitesi Sosyal Bilimler Enstitüsü Dergisi, 21(2), 419-426.

Şengül, M. (2012).Yabancı dil olarak Türkçe öğretiminde öğretim teknolojileri ve materyal kullanımı. Aziz Kılınç, Abdullah Şahin (Editörler). Yabancı dil olarak Türkçe öğretimi (ss. 168-210). 2. Baskı. Ankara: Pegem Akademi.

Şengül, K. (2014). Türkçenin yabancı dil olarak öğretiminde alfabe sorunu. Uluslararası Türkçe Edebiyat Kültür Eğitim Dergisi, 3(1), 325-339.

Yaman, M. ve Bozdemïr, O. (2005). Yabancı dil öğretiminde teknolojik yaklaşımlar. Atatürk Üniversitesi Kazım Karabekir Ĕ̈itim Fakültesi Dergisi, o(12), 219-235. 